\title{
Cytotoxicity Assay of Sodium Hypochlorite and QMix on Cultured Human Periodontal Ligament Fibroblast Cells
}

\author{
Dian Agustin Wahjuningrum¹, Makkunrai Eka Kramatawati Elizabeth ${ }^{1}$, Fikarini Hadi Puteri², Andi Ainul Mardiyah' ${ }^{1}$, Ari Subiyanto ${ }^{1}$ \\ ${ }^{1}$ Department of Conservative Dentistry, Faculty of Dental Medicine, Universitas Airlangga, Surabaya, Indonesia, ${ }^{2}$ Faculty of Biosciences and Medical \\ Engineering, Universiti Teknologi Malaysia, Johor Bahru, Johor Darul Ta`zim, Malaysia
}

\section{Abstract}

Aims and Objectives: Sodium hypochlorite $(\mathrm{NaOCl})$ and QMix are solutions used for root canal irrigation. During the endodontic procedure, irrigation solutions are often leaked beyond the apical foramen and as a result cause periapical tissue complication because of their toxicity. This study was aimed at proving the cytotoxicity effect of $\mathrm{NaOCl}$ and QMiX on cultured human periodontal ligament fibroblast cells (HPDLFc). Materials and Methods: HPDLFc were exposed to $\mathrm{NaOCl}$ and QMix at various concentrations. Cell viability was assessed with Mosmann's tetrazolium toxicity assay and the results were measured and statistically analyzed by probit analysis to determine the median lethal concentration (LC50), the concentration that is lethal to $50 \%$ of the cells and therefore considered cytotoxic. Results: $\mathrm{NaOCl}$ and QMix are cytotoxic to HPDLFc at 0.254 and $0.363 \mu \mathrm{L} / \mathrm{mL}$, respectively. Conclusion: Both solutions are cytotoxic to HPDLFc at certain concentrations.

Keywords: Cytotoxicity, Fibroblast Cells, Irrigants, Qmix, Sodium Hypochlorite

\section{INTRODUCTION}

The principle of root canal treatment comprises three important stages known as endodontic triads, which include biomechanical preparation, disinfection, and obturation of root canals. Mechanical preparation using designated instrument must be followed by chemical preparation through irrigation. ${ }^{[1]}$ Some irrigation solutions used in these treatments include sodium hypochlorite $(\mathrm{NaOCl})$, chlorhexidine gluconate $(\mathrm{CHX})$, chelating agent (ethylenediaminetetraacetic acid [EDTA]), normal saline, and QMix.

$\mathrm{NaOCl}$ is widely used as an endodontic irrigation solution due to its antimicrobial activity and its ability to dissolve the remnants of necrotic tissue. It is also useful as a lubricant and is capable of inactivating bacterial endotoxin. However, it is usually used as an irrigation solution at a concentration range of $0.5 \%-5.25 \%{ }^{[2]} \mathrm{QMix}$ is a solution containing a combination of EDTA (17\%), CHX (2\%), and surfactant for root canal irrigation. This solution is effective for the removal of smear layers and also has antimicrobial substances. ${ }^{[3]}$

\begin{tabular}{|l|l|}
\hline \multicolumn{2}{|c|}{ Access this article online } \\
\hline Quick Response Code: & Website: \\
& www.jioh.org \\
\hline & \\
\hline
\end{tabular}

On the basis of a research conducted by Jose et al. (2016), ${ }^{[3]}$ it was discovered that the antimicrobial effects of QMix on Enterococcus faecalis and Candida albicans were better than $2 \% \mathrm{CHX}$ and $2.5 \% \mathrm{NaOCl}$. However, the CHX and EDTA content in QMix irrigation solution can result in cell death by inhibiting mitochondrial activity, together with deoxyribonucleic acid (DNA), and protein syntheses. ${ }^{[4]}$ According to the in vivo study conducted by Chandrasekhar et al. ${ }^{[5]}$ (2013) on the biocompatibility of QMix, it was discovered that its toxicity on rat subcutaneous tissue was less than $3 \% \mathrm{NaOCl}$. In vitro research conducted by AlKahtani et al. ${ }^{[6]}$ (2014) on the cytotoxicity of this same solution on human bone marrow mesenchymal stem cells revealed that the viability of cells exposed to $0.5 \mu \mathrm{g} / \mathrm{mL} \mathrm{NaOCl}(5.25 \%)$ was significantly lower when compared with cells exposed to $0.5 \mu \mathrm{g} / \mathrm{mL}$ of

Address for correspondence: Dr. Dian Agustin Wahjuningrum Department of Conservative Dentistry, Faculty of Dental Medicine, Universitas Airlangga-Indonesia, Prof. Dr. Moestopo 47, Surabaya-Jawa Timur, Indonesia 60132 E-mail: dian-agustin-w@fkg.unair.ac.id

This is an open access journal, and articles are distributed under the terms of the Creative Commons Attribution-NonCommercial-ShareAlike 4.0 License, which allows others to remix, tweak, and build upon the work non-commercially, as long as appropriate credit is given and the new creations are licensed under the identical terms.

For reprints contact: reprints@medknow.com

How to cite this article: Wahjuningrum DA, Elizabeth ME, Puteri FH, Mardiyah AA, Subiyanto A. Cytotoxicity assay of sodium hypochlorite and QMix on cultured human periodontal ligament fibroblast cells. J Int Oral Health 2019;11:204-7. 
QMix. These previous studies revealed that QMix is more biocompatible than $\mathrm{NaOCl}$.

An ideal irrigation solution should be nontoxic, have broad antimicrobial properties, capable of dissolving pulp necrotic tissue, inactivate endotoxin, and prevent or dissolve the formation of the smear layer..$^{[4]}$ During the endodontic treatment, the irrigation solution may leak from the apical foramen and may cause inflammation to the surrounding periapical tissue, thereby inhibiting healing and regeneration of this tissue..$^{[5]}$

The cells required in the regeneration of periodontal ligaments are fibroblast cells. This is the first cell to come into contact when the irrigant extrudes from the apical foramen. Human periodontal ligament fibroblast cells (HPDLFc) are the main cells that react to endodontic substances in periapical tissue and they are also the type most frequently studied for periodontal regeneration. ${ }^{[6]}$

The cytotoxicity of an irrigant on HPDLFc can be observed from the median lethal concentration (LC50), which shows the material's ability to cause $50 \%$ cell culture death. ${ }^{[7]}$ A substance is said to be toxic if the percentage of living cells after the exposure of the substance is less than $50 \% \cdot{ }^{[8-10]}$

This study was aimed at proving the cytotoxicity effect of $\mathrm{NaOCl}$ and QMiX on cultured HPDLFc.

\section{Materials and Methods}

This research was that of an experimental laboratory using only posttest control group design, and the minimum number of samples required was two for each group according to the calculation of Lemeshow. Cytotoxicity of solutions was evaluated on cultured HPDLFc in the laboratory at the Faculty of Dental Medicine, Universitas Airlangga, Indonesia. The study protocol had been previously approved by the ethics committee of the faculty (ID: IR.UMSHA.REC.1396.496).

Premolar tooth extracted for orthodontic purpose was rinsed with saline solution and stored in a $15-\mathrm{mL}$ tube containing Dulbecco's Modified Eagle Medium (DMEM) (Sigma-Aldrich, D5030-10L, St. Louis, Missouri), which had been added with fungi zone and pen strep. Periodontal ligaments on the one-third apical of the tooth root were then scraped using tweezers, placed in a Petri dish containing 10\% fetal bovine serum (Gibco, Grand Island, New York), antibiotics, and complete DMEM medium. Subsequently, they were incubated in a humidified atmosphere, $95 \%$ air and $5 \% \mathrm{CO}_{2}$ concentration, under $37^{\circ} \mathrm{C}$ in a water-based incubator for $24 \mathrm{~h}$.

After the cells reached $90 \%$ confluence on the petri dish, the remaining periodontal tissue together with the DMEM was discarded, and this was followed by washing the petri dish three times using phosphate-buffered solution (PBS) (P7994-1EA; Sigma-Aldrich). Afterward, trypsin (T2600000; Sigma-Aldrich) and EDTA (Sigma-Aldrich) were added to detach adherent HPDLFc from the petri dish and then transferred for centrifugation at $1200 \mathrm{rpm}$ for $5 \mathrm{~min}$. After removing the supernatant, $10 \%$ complete DMEM was added to the HPDLFc pellet and placed in a $5 \% \mathrm{CO}_{2}$ incubator at $37^{\circ} \mathrm{C}$ until $80 \%$ confluence was reached.

On the 96-well plates, $100 \mu \mathrm{L}$ HPDLFc suspension with a density of $200 \mathrm{cells} / \mu \mathrm{L}$ was added to each well and then set aside for $1-2 \mathrm{~h}$. Afterward, the same volume of $\mathrm{NaOCl}$ or QMix solutions with varying concentrations was added to each well to reach a total volume of $200 \mu \mathrm{L}$. Incubation lasted for $24 \mathrm{~h}\left(5 \% \mathrm{CO}_{2}, 37^{\circ} \mathrm{C}\right.$ temperature, $98 \%$ moisture $)$.

After $24 \mathrm{~h}$, the solution was examined under a microscope, after which the existing medium was removed. A total of $100 \mu \mathrm{L}$ of MTT solution was prepared by dissolving $5 \mathrm{mg}$ of 3-(4,5-dimethyl-2-thiazolyl)-2, 5-diphenyl-2Htetrazolium bromide (Sigma-Aldrich Co., St. Louis, MO, USA) in $1 \mathrm{~mL}$ of PBS. After filtering, this solution was diluted from 1 to 10 using DMEM; $400 \mu \mathrm{L}$ of the diluted MTT solution was added to each well and plates, which were then incubated at $37^{\circ} \mathrm{C}$ under $5 \% \mathrm{CO}_{2}$ and $95 \%$ humidity for $4 \mathrm{~h}$. After the dissolution of formazan crystals, optical density of the solution was read at 540-690 nm using enzyme-linked immunosorbent assay (ELISA) Reader (Bio Tek, Winooski, Vermont). The living HPDLFc would be stained by formazan to blue color, whereas the dead would not.

The result of spectrophotometer reading indicated the optical density (OD) of each sample. These OD values were used in calculating the percentage of HPDLFc death caused by different concentrations of irrigants, using the following formula:

$$
\% \text { Mortality }=\frac{\text { OD control }- \text { OD sample }}{\text { OD Control }} \times 100 \%
$$

On the basis of the aforementioned formula, concentration of certain irrigants to cause \% mortality closest to LC50 could be discovered. The exact concentration corresponding to LC50 was calculated using probit analysis.

\section{REsULTS}

The concentration of $\mathrm{NaOCl}$, which resulted in the percentage of death closest to LC50 was $0.25 \mu \mathrm{L} / \mathrm{mL}$. Calculation using probit analysis revealed $\mathrm{NaOCl}$ concentration, which corresponded to LC50, was $0.254 \mu \mathrm{L} / \mathrm{mL}$ [Figures 1 and 2]. The concentration of QMix, which brought about the percentage of death closest to LC50 was between 0.5 and $0.25 \mu \mathrm{L} / \mathrm{mL}$. Calculation using probit analysis revealed QMix concentration corresponding to LC50 was $0.363 \mu \mathrm{L} / \mathrm{mL}$ [Figures 3 and 4] 


\section{Discussion}

This study was conducted to determine the cytotoxicity of $\mathrm{NaOCl}$ and QMix as irrigation solutions. $\mathrm{NaOCl}$ is the most commonly used irrigation solution in endodontic procedure due to its antimicrobial property and its ability to dissolve organic material. ${ }^{[2]}$ The results of its cytotoxicity test showed that it caused $50 \%$ of cell death at concentrations of $0.254 \mu \mathrm{L} / \mathrm{mL}$.

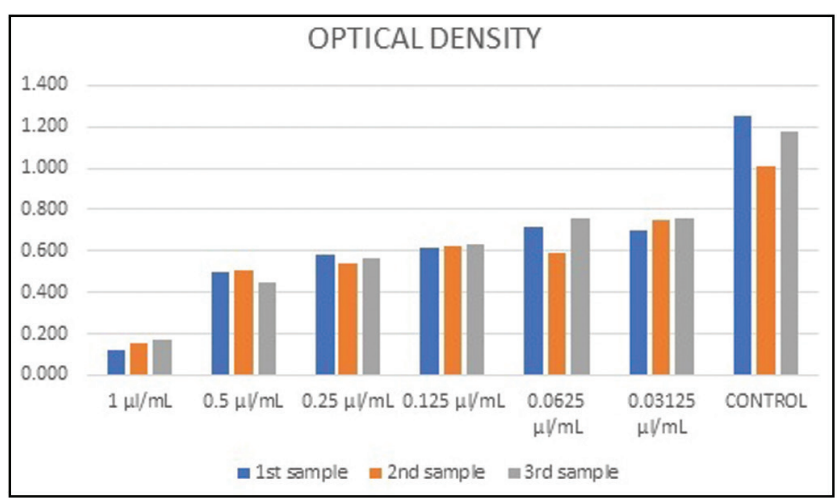

Figure 1: Optical density of each sample with varying concentrations of sodium hypochlorite

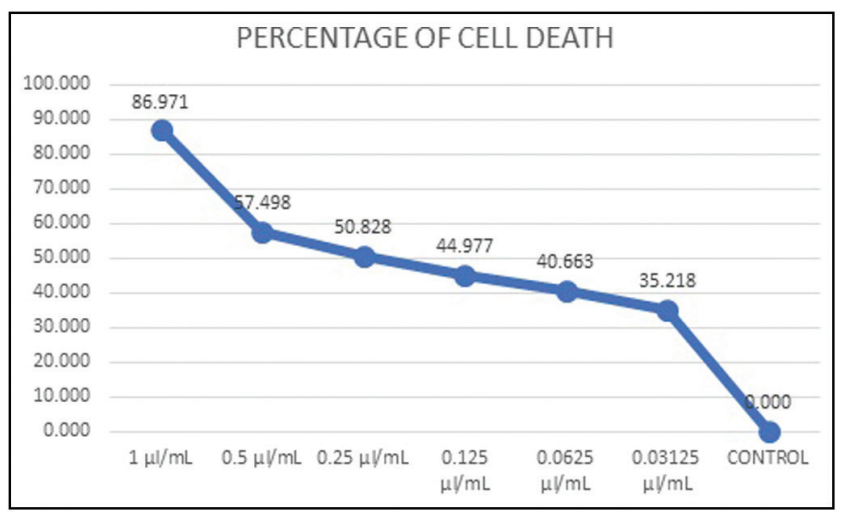

Figure 2: Percentage of human periodontal ligament fibroblast cells death with varying concentrations of sodium hypochlorite

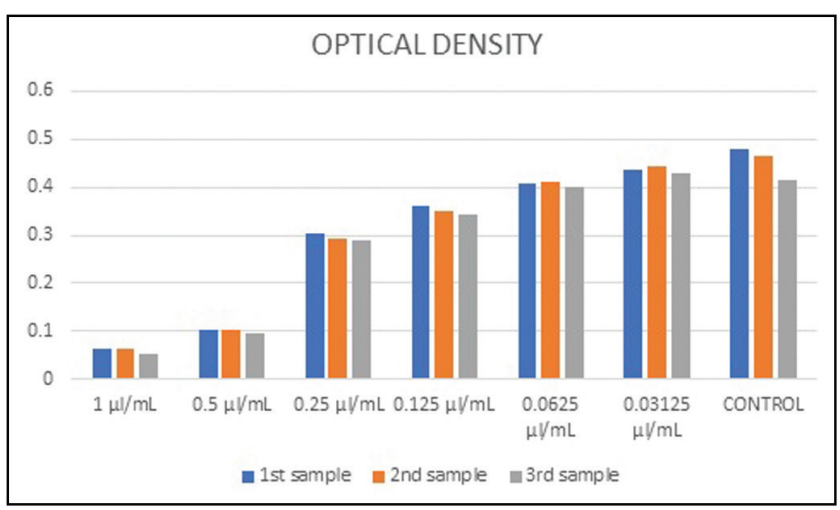

Figure 3: Optical density of each sample with varying concentrations of QMix
$\mathrm{NaOCl}$ produces hypochlorous acid (HOCL), which is an oxidizing agent acting as a solvent and when it comes in contact with organic tissue, it releases chlorine. ${ }^{[11]}$ However, chlorine can trigger the onset of free radicals, which will increase reactive oxygen species (ROS). In addition, $\mathrm{NaOCl}$ has a high $\mathrm{pH}$ that triggers the release of hydroxyl ions. This release causes a change in the integrity of the cytoplasmic membrane resulting from damage to the mitochondria. This damage can result in the formation of channels in mitochondrial membranes called mitochondrial permeability transition pore. The existence of this channel will result in the failure of oxidative phosphorylation and reduced Adenosine triphosphate (ATP). An abnormality in oxidative phosphorylation instigates the formation of ROS. Increased ROS leads to oxidative stress in cells, which brings about lipid peroxidation, impaired protein synthesis, and DNA damage. These effects, as well as a reduced ATP all result in cell death. ${ }^{[12-14]}$

QMix is a solution containing 17\% EDTA, 2\% CHX, and surfactant for root canal irrigation. In addition, it is effective in the removal of smear layers and has antimicrobial substances. ${ }^{[7,15,16]}$ Its cytotoxicity test results showed that it caused $50 \%$ of cell death at concentrations of $0.363 \mu \mathrm{L} / \mathrm{mL}$.

QMix causes death in cells because of its contents. ${ }^{[17,18]}$ CHX in contact with the tissue will bind to the plasma membrane of cells, causing membrane permeability to increase, and this results in an increase in the amount of intracellular $\mathrm{Ca}^{2+}$. This causes leakage of the lysosomal enzymes that have potential for cell death, such as phospholipase (membrane damage), proteases (membrane damage and cytoskeletal proteins), endonuclease (breakdown of DNA and chromatin), and ATPase, also defined as F1FO-ATP synthase or Complex V, is located in the inner mitochondrial membrane together with the ETC Complexes I-IV (accelerates the reduction of oxygen). ${ }^{[1]}$ EDTA in addition to binding calcium also binds to heavy metal ions. The mechanism of cell toxicity is due to its

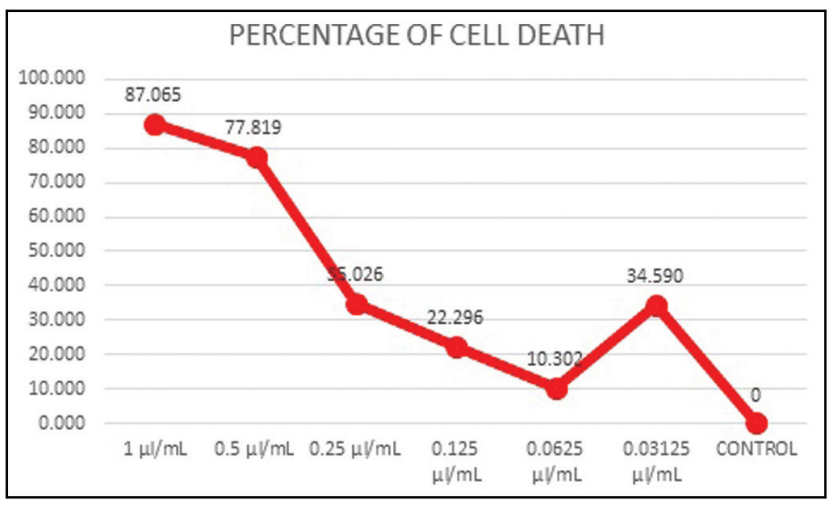

Figure 4: Percentage of human periodontal ligament fibroblast cells death with varying concentrations of QMix 
interaction as a chelating agent with endogenous metal inorganic ions in cells. Free metal ions, both endogenous and exogenous, have a high affinity for DNA. However, EDTA is difficult to penetrate cell membranes but acts as an extra cell-chelating agent, binding inorganic ions that help it to penetrate into the cells, which results in the interference with the structure and permeability of cell membranes. ${ }^{[19,20]}$ This disorder causes mitochondrial dysfunction. Moreover, this dysfunction of cells, because of CHX and EDTA, causes increased ROS, resulting in oxidative stress in cells and this stress damages DNA, triggering cell death.

There are limitations in this study such as not considering the dynamics contained in root canals, including biofilm surface defense mechanism of endodontic microflora and immune responses that are different individually as this study is limited to cultured HPDFLc only. Further in vivo study is needed in terms of the biocompatibility aspect of these materials.

In conclusion, $\mathrm{NaOCl}$ and $\mathrm{QMix}$ were found to be cytotoxic to HPDLFc at 0.254 and $0.363 \mu \mathrm{L} / \mathrm{mL}$, respectively.

\section{Financial support and sponsorship}

Nil.

\section{Conflicts of interest}

There are no conflicts of interest.

\section{RefERENCES}

1. Roberson TM, Heymann H, Swift EJ, Sturdevant CM. Sturdevant's Art \& Science of Operative Dentistry. 4th ed. St. Louis, Missouri: Mosby; 2006. p. 74.

2. Chandra BS, Gopikrishna V. Grossman's Endodontic Practice. 13rd ed. New Delhi: Wolters Kluwer; 2014. p. 328.

3. Jose J, Krishnamma S, Peedikayil F, Aman S, Tomy N, Mariodan JP. Comparative evaluation of antimicrobial activity of QMiX, 2.5\% sodium hypochlorite, $2 \%$ chlorhexidine, guava leaf extract and aloe vera extract against Enterococcus faecalis and Candida albicans-An in-vitro study. J Clin Diagn Res 2016;10:ZC20-3.

4. Chang YC, Huang FM, Tai KW, Chou MY. The effect of sodium hypochlorite and chlorhexidine on cultured human periodontal ligament cells. Oral Surg Oral Med Oral Pathol Oral Radiol Endod 2001;92:446-50.
5. Chandrasekhar V, Amulya V, Rani VS, Prakash TJ, Ranjani AS, Gayathri Ch. Evaluation of biocompatibility of a new root canal irrigant Qmix $^{\mathrm{TM}} 2$ in 1 -An in vivo study. J Conserv Dent 2013;16:36-40.

6. Alkahtani A, Alkahtany SM, Mahmood A, Elsafadi MA, Aldahmash AM, Anil S. Cytotoxicity of Qmix $^{\mathrm{TM}}$ endodontic irrigating solution on human bone marrow mesenchymal stem cells. BMC Oral Health 2014;14:27.

7. Dai L, Khechen K, Khan S, Gillen B, Loushine BA, Wimmer CE, et al. The effect of Qmix, an experimental antibacterial root canal irrigant, on removal of canal wall smear layer and debris. J Endod 2011;37:80-4.

8. Zehnder M. Root canal irrigants. J Endod 2006;32:389-98.

9. Zhang M, Aguilera D, Das C, Vasquez H, Zage P, Gopalakrishnan V, et al. Measuring cytotoxicity: A new perspective on LC50. Anticancer Res 2007;27:35-8

10. Khoswanto C, Arijani E, Soesilawati P. Cytotoxicity test of 40, 50 and $60 \%$ citric acid as dentin conditioner by using MTT assay on culture cell line. Dental J 2008;41:103-6.

11. Hargreaves, Kenneth M, Cohen S, Berman LH. Cohen's Pathways of the Pulp. 11th ed. St. Louis, MO: Mosby Elsevier; 2016. p. 251-2.

12. Harris JB. Comparison of Steriplex ${ }^{\mathrm{TM}} \mathrm{HC}$ and sodium hypochlorite cytotoxicity on primary human gingival fibroblasts. A thesis, Dentistry at Virginia Commonwealth University; 2012.

13. Mohmmed SA, Vianna ME, Penny MR, Hilton ST, Knowles JC. The effect of sodium hypochlorite concentration and irrigation needle extension on biofilm removal from a simulated root canal model. Aust Endod J 2017;43:102-9.

14. Hidalgo E, Bartolome R, Dominguez C. Cytotoxicity mechanisms of sodium hypochlorite in cultured human dermal fibroblasts and its bactericidal effectiveness. Chem Biol Interact 2002;139:265-82.

15. Souza MA, Montagner A, Lana DL, Vidal CM, Farina AP, Cecchin D. Comparative evaluation of the retaining of Qmix and chlorhexidine formulations on human dentin: A chemical analysis. Clin Oral Investig 2017;21:873-8.

16. Nogo-Živanović D, Kanjevac T, Bjelović L, Ristić V, Tanasković I. The effect of final irrigation with MTAD, QMix, and EDTA on smear layer removal and mineral content of root canal dentin. Microsc Res Tech 2019;82:923-30.

17. Küçük M, Kermeoğlu F. Efficacy of different irrigation methods on dentinal tubule penetration of chlorhexidine, QMix and irritrol: A confocal laser scanning microscopy study. Aust Endod J 2018;1-7.

18. Yılmaz K, Tüfenkçi P, Adıgüzel M. The effects of QMix and Endo Activator on postoperative pain in mandibular molars with nonvital pulps: A randomized clinical trial. Clin Oral Investig 2019;27:1-8.

19. Scanlon C, Marchesan J, Soehren S, Matsuo M, Kapila Y. Capturing the regenerative potential of periodontal ligament fibroblasts. J Stem Cells Regen Med 2011;7:54-6.

20. Hülsmann M, Heckendorff M, Lennon A. Chelating agents in root canal treatment: Mode of action and indications for their use. Int Endod J 2003;36:810-30. 